\title{
THE CONSTITUTIONALITY OF THE WAR POWERS RESOLUTION
}

\author{
Stephen L. Carter*
}

\begin{abstract}
A NYONE wishing to argue that the War Powers Resolution of $1973^{1}$ is unconstitutional must be prepared to explain the purpose of article I, section 8, clause 11, of the Constitution. That provision expressly grants to Congress the power "To declare War." If the President of the United States is free to fight a war whether or not one has been declared, then this apparently unambiguous constitutional provision is devoid of significance.

Opponents of the War Powers Resolution have traditionally claimed that clause 11 confers upon Congress only a narrow piece of war power. ${ }^{3}$ Defenders of the Resolution have argued in contrast that the Resolution constitutes an exercise of congressional authority under the clause. ${ }^{4}$ This last contention pokes at the truth without quite striking it. The War Powers Resolution is not constitutional as an exercise of the war power. It is constitutional because it defines the war power. The War Powers Resolution is nothing more or less than a congressional definition of the word "war" in
\end{abstract}

*Assistant Professor of Law, Yale University. I am deeply indebted to Enola G. Aird, Charles Black, and Martha Minow, whose comments on all or part of this article kept me from going too far wrong; to Don Elliott, for discussing these ideas with me when they were yet in quite a primitive stage of development and for encouraging me to put my thesis down on paper; and to Dean Hashimoto and David Rubin for research assistance that was both remarkable and invaluable.

${ }^{2} 50$ U.S.C. $\$ \S 1541-1548$ (1976 \& Supp. V 1981).

2 U.S. Const. art. I, § 8, cl. 11.

s See, e.g., Emerson, The War Powers Resolution Tested: The President's Independent Defense Power, 51 Notre Dame Law. 187, 209-13 (1975) (arguing Congress may declare "offensive" wars); Rostow, Great Cases Make Bad Law: The War Powers Act, 50 Tex. L. Rev. 833, 864-66 (1972) (some "undeclared wars" constitutionally legitimate).

- See, e.g., A. Sofaer, War, Foreigu Affairs and Constitutional Power 56 (1976) (by implication); Lofgren, War-Making Under the Constitution: The Original Understanding, 81 Yale L.J. 672, 699-702 (1972) (by implication). Some commentators have quickly conceded the Resolution's constitutionality, but have doubted whether it will resolve the problem at which it is aimed. See, e.g., L. Henkin, Foreign Affairs and the Constitution 103 (1972) (stating provision is "surely" within power of Congress, but President can "exploit its ambiguities and uncertainties"). 
article I. A definition of this kind coupled with a reasonable enforcement mechanism is well within the power of Congress under a proper understanding of the constitutional system of checks and balances. The definition does not intrude on any presidential prerogative. The mechanisms chosen by Congress to enforce the provisions of the Resolution were reasonable in 1973 and, although matters have been complicated by the United States Supreme Court's decision late last Term in Immigration and Naturalization Service $v$. Chadha, ${ }^{\mathrm{b}}$ those mechanisms remain reasonable today.

\section{The War Powers Conundrum}

\section{A. The Resolution}

The War Powers Resolution of $1973,{ }^{\circ}$ forced on a weakened President Nixon by a Congress brimming with confidence in the wake of the Watergate scandals, was controversial from the beginning. To its supporters, the Resolution represented a congressional effort to exercise its constitutional prerogative to decide when to send the nation to war. ${ }^{7}$ To opponents, the Resolution was an inexcusable usurpation by the legislative branch of the powers of the executive. ${ }^{8}$ To cynics, it was Congress' way of pretending that the Vietnam War had somehow been a fast one pulled by the executive branch, rather than a disaster jointly managed by two Presidents and five Congresses. ${ }^{9}$

Wary of arguments that the Resolution exceeded congressional authority, the conference committee that drafted the Resolution in

B 103 S. Ct. 2764 (1983).

${ }^{6} 50$ U.S.C. $\S \S 1541-1548$ (1976 \& Supp. V 1981). President Nixon vetoed the bill incorporating the Resolution, but his veto was overridden. H.R.J. Res. 542, 87 Stat. 555, 560 (1973). The War Powers Resolution has entered the arena of public debate under the name "War Powers Act," but the legislative history reflects a conscious decision by the Congress to refer to the measure as a "Resolution" rather than as an "Act." See Conf. Rep. No. 547, 93d Cong., 1st Sess. 1, reprinted in 1973 U.S. Code Cong. \& Ad. News 2363, 2363.

7 See, e.g., L. Henkin, supra note 4, at 100-04; Berger, War-Making by the President, 121 U. Pa. L. Rev. 29 (1972). There are also those who believe that the War Powers Resolution does not place on the President as many limits as it should. See, e.g., Friedman, Waging War Against Checks and Balances-The Claim of an Unlimited Presidential War Power, 57 St. John's L. Rev. 213, 262-63 (1983).

s See, e.g., Emerson, supra note 3, at 201-15; Rostow, supra note 3, at 843.

' See, e.g., Hecht, Commander-in-Chief: Who "Makes" War?, 127 America, Aug. 19, 1972, at 90, 93 (arguing Resolution merely enables "politicians to put themselves on record as opposing [the Vietnam] war"). 
its final form took care to limit its apparent scope. ${ }^{10}$ As adopted, the Resolution states a straightforward goal:

It is the purpose of this joint resolution to fulfill the intent of the framers of the Constitution of the United States and insure that the collective judgment of both the Congress and the President will apply to the introduction of the United States Armed Forces into hostilities, or into situations where imminent involvement in hostilities is clearly indicated by the circumstances, and to the continued use of such forces in hostilities or in such situations."1

In short, the purpose of the Resolution, as stated by its drafters, is to make certain that the President does not commit troops without the consent of Congress. ${ }^{12}$

To accomplish this end, section 3 of the Resolution requires that the President "in every possible instance shall consult with Congress" before sending American troops "into hostilities or into situations where imminent involvement in hostilities is clearly indicated by the circumstances." ${ }^{\text {"1s }}$ Section 4 requires the President to send a report within forty-eight hours when, absent a declaration of war, he introduces American forces

(1) into hostilities or into situations where imminent involvement in hostilities is clearly indicated by the circumstances;

(2) into the territory, airspace or waters of a foreign nation, while equipped for combat, except for deployments which relate solely to supply, replacement, repair, or training of such forces; or

(3) in numbers which substantially enlarge United States Armed Forces equipped for combat already located in a foreign nation. ${ }^{14}$

This reporting requirement is critical because it triggers the limitation that the last four Presidents have found most vexing. Within sixty days after the report is actually submitted or is required to be submitted, whichever comes first, section 5 of the Resolution directs that "the President shall terminate any use of United

10 Thus, "the President's right to defend the Nation against attack" was expressly recognized. H.R. Rep. No. 287, 93d Cong., 1st Sess. 5, reprinted in 1973 U.S. Code Cong. \& Ad. News 2346, 2349. See also Conf. Rep. No. 547, supra note 6, reprinted in 1973 U.S. Code Cong. \& Ad. News at 2364.

11 War Powers Resolution § 2(a), 50 U.S.C. § 1541(a) (1976).

12 See H.R. Rep. No. 287, supra note 10, reprinted in 1973 U.S. Code Cong. \& Ad. News at 2349-50.

13 War Powers Resolution § 3, 50 U.S.C. § 1542 (1976).

14 Id. $\S 4(\mathrm{a}), 50$ U.S.C. $\$ 1543(\mathrm{a})$ (1976). 
States Armed Forces with respect to which such report was submitted (or required to be submitted)." Section 5 does not apply, however, if Congress either declares war or enacts specific enabling legislation, extends the sixty-day period, or, most chilling of all, "is physically unable to meet as a result of an armed attack upon the United States."1s Section 5 further provides that, whenever American forces "are engaged in hostilities outside the territory of the United States" in the absence of specific authorization, "such forces shall be removed by the President if the Congress so directs by concurrent resolution."16

No President has ever formally conceded the constitutionality of the War Powers Resolution, although Presidents Ford and Carter complied with its terms. ${ }^{17}$ Until recently, Congress had never formally invoked the provisions giving it ultimate authority over the deployment of American forces. ${ }^{18}$ The Resolution has again become news, however, because of two decisions made by President Reagan during 1983. The first was his decision to send Marines and units of the Navy to participate in an international peacekeep-

${ }^{15}$ Id. $\S 5$ (b), 50 U.S.C. $\$ 1544$ (b) (1976). The President may extend this period for an additional 30 days if he "determines and certifies to the Congress in writing that unavoidable military necessity respecting the safety of United States Armed Forces requires the continued use of such armed forces in the course of bringing about a prompt removal of such forces." Id. Whenever this article makes reference to a "sixty-day period," it should be understood that the President may unilaterally extend that period to 90 days.

${ }^{16}$ Id. § 5(c), 50 U.S.C. § 1544(c) (1976).

17 As required by $\S 4$ (a) of the Resolution, President Ford informed the Speaker of the House and the President Pro Tempore of the Senate within 48 hours of sending American forces to free the S.S. Mayaguez after it was seized by Cambodia. See Letter to the Speaker of the House and the President Pro Tempore of the Senate Reporting on United States Actions in the Recovery of the SS Mayaguez, 1975 Pub. Papers 669. President Ford, however, declined to concede that he was required to send the report, stating that his letter was sent "[i]n accordance with my desire that the Congress be informed on this matter and taking note of $\$ 4(a)(1)$ " of the Resolution. Id. (emphasis added). Similarly, President Carter sent a letter within 48 hours of the attempt by American forces to rescue the hostages held in Iran. See Letter to the Speaker of the House and the President Pro Tempore of the Senate Reporting on the Operation, 1980-81 Pub. Papers 777. President Carter stated that his report was "consistent with" the requirements of $\S 4(\mathrm{a})$. Id. (emphasis added). President Carter also refused to concede that the Resolution limited his inherent power to act, although he stated that his authority as Commander-in-Chief was "expressly recognized in $\S 8(d)(1)$ " of the Resolution. Id. at 779. President Ford's letter made no reference to the Resolution's limitations on the President's freedom of action.

${ }^{18}$ Of course, except for the matters mentioned previously, supra note 17 , there has until now been no claim that American forces were deployed abroad in a fashion that triggered the requirements of the Resolution. 
ing force in Lebanon. The second was his decision to send Marines and Army Rangers to invade and occupy ${ }^{19}$ the island of Grenada.

Almost from the time the American forces arrived in Lebanon, congressional critics called on the President to comply with the requirements of the Resolution and officially inform Congress that the troops were involved either in hostilities or in a "situatio[n] where imminent involvement in hostilities is clearly indicated by the circumstances." ${ }^{20}$ The White House response was to deny that the terms of the Resolution were met by the situation in Lebanon because any "hostilities" were not directed at the American forces. ${ }^{21}$ Meanwhile, behind the scenes, Reagan Administration officials were insisting that the Resolution was not constitutional. ${ }^{22}$ When continuing attacks on United States positions in and around Beirut caused casualities among Marines and forced American troops to retaliate, the hollowness of the "no hostilities" position was laid bare. The Administration then negotiated a compromise with the Congress. The President would not formally concede the constitutional validity of the War Powers Resolution, but if Congress chose to adopt a joint resolution "permitting" the Marines to remain in Lebanon for eighteen months, the President would sign it. $^{23}$ Although many members of Congress expressed dissatisfaction

10 There has been much talk in the media about whether the Grenada mission should be referred to as an invasion or as something else-a rescue or a liberation, perhaps. But those are justifications for invasion; they do not render the landing of troops on foreign soil without the consent of the foreign government any less an invasion. Thus, for example, the liberation of Europe during World War II followed the invasion on D-Day. The invasion of Normandy was certainly justified, but it was still an invasion.

${ }^{20}$ See, e.g., Eagleton, Our Troops in Lebanon, N.Y. Times, Nov. 17, 1982, at A35, col. 2 (Senator contending that commitment of forces in Lebanon triggered the War Powers Resolution). These calls intensified after American soldiers died in the fighting. See N.Y. Times, Aug. 30, 1983, at A8, col. 1 (quoting members of Congress).

${ }^{21}$ See, e.g., N.Y. Times, Aug. 29, 1983, at A8, col. 3 (letter from the President to Congress); id., Sept. 1, 1983, at A1, col. 5 (statement by Secretary of State Shultz).

${ }^{22}$ See, e.g., N.Y. Times, Sept. 21, 1983, at A16, col. 1 (stating Administration believes Resolution "infringes on the President's flexibility as Commander in Chief"). See also Getting into the Act, Time, Sept. 26, 1983, at 14 (summarizing public debate). More questions about the constitutionality of the War Powers Resolution were raised in the wake of the Supreme Court's decision in Immigration \& Naturalization Serv. v. Chadha, 103 S. Ct. 2764 (1983). See Destler, Life After the Veto, Foreign Pol'y, Fall 1983, at 181, 183; N.Y. Times, June 29, 1983, at A19, col. 1. The effect of Chadha on the constitutional validity of the War Powers Resolution is discussed infra text accompanying notes 124-41.

${ }^{23}$ See Smith, Peace Keeping Gets Tough, Time, Sept. 19, 1983, at 32, 34; N.Y. Times, Sept. 13, 1983, at A1, col. 5; N.Y. Times, Sept. 8, 1983, at A1, col. 5. The early sticking point in compromise negotiations was the Reagan Administration's preference for a resolution 
with the compromise, the joint resolution was adopted and signed by the President in the autumn of $1983 .{ }^{24}$

The compromise did nothing to lay to rest the argument over the Resolution's constitutionality, however. In fact, congressional sentiment to force an end to the mission of the Marines in Lebanon has renewed in the wake of the October bombing of the Marine barracks in Beirut that killed over 240 American servicemen. ${ }^{25}$ As this is being written, there is some prospect that Congress might try to exercise its authority under section 5(c) to order the President to withdraw all American troops from Lebanon. ${ }^{28}$ Even if Congress should fail to act before the compromise expires, the legislators seem unlikely to extend the mission any further. Moreover, when the eighteen months have expired, if the Marines are still fighting and the executive branch wants them to stay, the constitutional issue will have to be faced.

The invasion of Grenada initially seemed likely to precipitate a clash between the President and Congress. ${ }^{27}$ As broad public support for the President's decision to send troops to the island became apparent, however, congressional calls for formal invocation of the War Powers Resolution faded. ${ }^{28}$ After the disaster in Beirut, many Americans were anxious to see their nation's armed forces in a successful combat role, and many saw the invasion as morally correct to eliminate a perceived threat to stability in the region. In addition, the White House made good on its promise to bring all

that would avoid any mention of the War Powers Resolution. N.Y. Times, Sept. 14, 1983, at A14, col. 6.

${ }^{24}$ For the text of the compromise resolution, see Multinational Force in Lebanon Resolution, Pub. L. No. 98-119, 1983 U.S. Code Cong. \& Ad. News (97 Stat.) 805.

${ }^{25}$ See N.Y. Times, Oct. 25, 1983, at A16, col. 1 (congressional leaders ponder cut-off of funds); id., Dec. 30, 1983, at A1, col. 6 (congressional leaders consider War Powers Resolution action).

${ }^{28}$ See N.Y. Times, Jan. 12, 1984, at A10, col. 1 (growing congressional demands for action).

${ }^{27}$ See N.Y. Times, Oct. 27, 1983, at A18, col. 1. Within a week of the invasion, both houses of Congress adopted essentially identical measures invoking the War Powers Resolution. See id., Nov. 2, 1983, at A1, col. 6. But the Senate attached its resolution to a bill raising the debt ceiling, and before the two houses could reach agreement, the efforts to invoke the War Powers Resolution were essentially abandoned.

${ }^{28}$ Some members of Congress remained dissatisfied, however, and seven of them introduced a resolution calling for President Reagan's impeachment. See H.R. Res. 370, 98th Cong., 1st Sess., 129 Cong. Rec. H9706 (1983); N.Y. Times, Nov. 11, 1983, at A13, col. 1. Perhaps unsurprisingly, the resolution of impeachment has sunk without a trace. 
but a handful of American forces home from Grenada by the end of the sixty-day period in which the Resolution requires that they return. ${ }^{29}$ Nevertheless, some American forces remain on Grenada in an ostensibly civil role, and it is not easy to see why their continued presence is not a violation of the letter of the War Powers Resolution. ${ }^{30}$ In an election year, moreover, some candidates are bound to see the continuing commitment of American forces to Grenada as an exploitable issue. If American troops remain on the island, then one way or another, the Grenada invasion, too, may ultimately raise the issue whether the War Powers Resolution is constitutional.

Even should a confrontation be avoided over President Reagan's use of American forces in Lebanon or on Grenada, a constitutional showdown seems inevitable in the not-too-distant future. The use of American military force in the Middle East, in the Caribbean, and in Central America ${ }^{31}$ suggests that in the mid-1980's the United States has entered the world that the drafters of the War Powers Resolution feared in 1973. The world for which the Resolution was written is a world in which the United States is willing to use its armed might as an instrument of policy, even at the risk of protracted conflict. Yet when the nation takes that risk, it does so because military action is the chosen instrument of a President and his advisers, not of Congress. No matter what the final outcome of current disputes between the President and the Congress over the commitment of troops, in a world in which Presidents feel free to use force on their own initiative, the constitutional issue will come up again and again until it is finally resolved. ${ }^{\mathbf{3 2}}$

20 See N.Y. Times, Dec. 13, 1983, at A3, col. 4.

so This should not he taken as an assertion that any provision of the Resolution is necessarily enforceable by a court. See infra note 72 .

31 The death of an American helicopter pilot in Honduras, a death that even the Pentagon conceded was the result of "hostile fire," see N.Y. Times, Jan. 12, 1984, at A1, col. 3, suggests that even the combat forces taking part in the Defense Department's Big Pine II maneuvers might be involved in a "situatio[n] where imminent involvement in hostilities is clearly indicated by the circumstances," War Powers Resolution § 4(a)(1), 50 U.S.C. § 1543(a)(1) (1976), which would trigger the reporting and withdrawal requirements.

32 It might be argued that the constitutionality of the War Powers Resolution presents a nonjusticiable political question. Cf. Goldwater v. Carter, 444 U.S. 996, 1002-05 (1979) (plurality opinion) (suggesting that disputes between the President and the Congress over the conduct of foreigu policy are nonjusticiable). It hardly seems likely, however, that a Supreme Court willing to decide Chadha would shrink from considering the Resolution's constitutionality merely because it implicates the foreign affairs power. But see infra text ac- 


\section{B. Constitutionality: The Traditional Arguments}

The question whether the War Powers Resolution is constitutional has been debated since the Act was first passed over Nixon's veto. In his original veto message, President Nixon asserted that he had no choice but to reject the Resolution because it was "clearly unconstitutional." 33 Some members of the committee that drafted it said the same, ${ }^{34}$ and no President has ever conceded its constitutionality. In recent months, journalists have taken up the debate. ${ }^{35}$ And academic commentators have naturally sallied forth to do battle for both sides.

This last battle is in many respects the most important one because the work of these commentators provides the ammunition that the main combatants fire at one another. Among constitutional scholars, the struggle over the Resolution's constitutionality has been waged mainly on the hazardous battleground of "the original understanding." Both sides assert that the intentions and practices of the Framers of the Constitution support their arguments. Thus, the defenders of the Resolution contend that it "restores" the original balance of war powers between the President and the Congress. ${ }^{36}$ The opponents respond that it is precisely this

companying notes 66-67. Even if the issue were litigated and the Court did refuse to get involved, that would not render constitutional argument trivial, although legal niceties would in that event surely be thrust away from center stage.

ss See Veto of the War Powers Resolution, 1973 Pub. Papers 893 ("I believe that both these provisions [\$§ 5(b) \& 5(c)] are unconstitutional"-one of several objections under the heading "Clearly Unconstitutional."). President Nixon argued that the Framers left the relative war powers of the President and the Congress murky, and that matters are best left that way. Id.

34 See H.R. Rep. No. 287, supra note 10, reprinted in 1973 U.S. Code Cong. \& Ad. News at 2359 (supplemental views of Reps. Mailliard, Broomfield, Mathias, Guyer, and Vander Jagt) ("We ... doubt that the Congress can constitutionally terminate the President's authority by a failure to act"); id. at 2360 (minority views of Reps. Frelinghuysen, Derwinski, Thompson, and Burke) (Resolution's "most important provisions are probably unconstitutional").

ss Compare Lewis, Flouting the Law, N.Y. Times, Sept. 19, 1983, at A19, col. 1 (Resolution constitutional) with Will, War Powers Act and Common Sense Act, L.A. Times, Sept. 15,1983 , pt. 2, at 7, col. 1 (Resolution unconstitutional).

so See, e.g., Berger, supra note 7, at 30 ("In truth, the Constitution withheld from the President the powers claimed for him by Professor Rostow.") (emphasis in original); Eagleton, The August 15 Compromise and the War Powers of Congress, 18 St. Louis U.L.J. 1, 8-9 (1973) (stating Resolution would fulfill congressional obligation to define President's powers). Cf. Bickel, Congress, the President and the Power to Wage War, 48 Chi.-Kent L. Rev. 131, 146 (1971) (Congress ought to "reassert its own general authority in matters of war and peace and redefine the President's."). 
balance that the Resolution has upset. ${ }^{37}$

As with any other battle over what the Framers planned or expected, this one threatens to exhaust the ammunition on both sides long before a conclusion is reached. For example, supporters and opponents of the Resolution both note that the Articles of Confederation and the original draft of the Constitution from the Committee on Detail granted Congress broad discretion in the conduct of war, ${ }^{38}$ but in the course of the Convention, this was changed to the power "To declare War." constitutionality of the War Powers Resolution, this decision is critical. J. Terry Emerson, defending an independent presidential warmaking power, has argued that the alteration

is persuasive evidence that the framers intended the legislative branch to have less authority over military matters than it possessed under the Articles.

$\cdots \cdot$

... [T] he framers must have understood that there had been

${ }^{37}$ For a particularly colorful statement of this hypothesis, see Rostow, supra note 3, at 843 (War Powers Resolution "repudiates that history root and branch, and seeks to substitute parliamentary government for the tripartite constitution we have so painfully forged.").

38 The Articles of Confederation stated: "The United States in Congress assembled shall have the sole and exclusive right and power of determining on peace and war . . . ." Articles of Confederation art. IX, § 1 . The Committee-on-Detail draft granted Congress the power "To make war." 2 The Records of the Federal Convention of 1787, at 182 (M. Farrand rev. ed. 1937) [hereinafter cited as Records]. For general hackground on the practice under the Articles of Confederation, see A. Sofaer, supra note 4, at 15-25.

30 See 2 Records, supra note 38 , at 318-19. The precise nature of the debate surrounding this change has been dissected by any number of scholars, and it is not my purpose to repeat it here. As recorded in Madison's notes, the debato at the Convention occupies only two pages, and the other historical materials are fragmentary. Nevertheless, scholars have had a field day working out the "original understanding" on the war power. See, e.g., A. Sofaer, supra note 4, at 31-35, 51-52, 56; Berger, supra note 7, at 39-47; Bestor, Separation of Powers in the Domain of Foreign Affairs: The Original Intent of the Constitution Historically Examined, 5 Seton Hall L. Rev. 527, 602-13 (1974); Reveley, Constitutional Allocation of the War Powers Between the President and Congress: 1787-1788, 15 Va. J. Int'l L. 73, 96113 (1974); Rostow, supra note 3, at 843-51. My point is not that there is anything wrong with delving so deeply into the intentions of the Framers, although it is possible to carry a good thing too far. See generally Brest, The Misconceived Quest for the Original Understanding, 60 B.U.L. Rev. 204 (1980) (strict intentionalism not a tenable approach to constitutional decisioumaking). But when so many scholars probe so deeply and develop such disparate results, perhaps that is a signal that efforts should be directed toward other approaches. Fortunately, the constitutionality of the War Powers Resolution can be determined without important reference to the views of those who wrote or ratified the $\mathbf{1 7 8 7}$ Constitution. 
and would continue to be many instances in which hostilities would occur without declaration. ${ }^{40}$

He concluded that the only power granted to Congress was the power to declare an "offensive war." In other words, by removing from Congress the power to conduct a war, the Framers sought to grant the President substantial discretion over use of the armed forces.

Abraham Sofaer, in his book-length investigation into the constitutional distribution of the war powers, reaches quite a different conclusion on much the same evidence. ${ }^{42}$ According to Sofaer, those who wrote the Constitution planned to limit the President's inherent authority as Commander in Chief to "manag[ing] military engagements and other objectives authorized by Congress." $43 \mathrm{He}$ points to various discussions during the debates over the Constitution and in the Federalist to support his position.4 Sofaer concludes that, by altering the text of the Constitution to give Congress only the power to declare war, the Framers intended "to enable the President to respond to 'sudden attacks' without a declaration of war," adding that "nothing in the change signifies an intent to allow the President a general authority to 'make' a war in the absence of a declaration." 45 In other words, by changing the constitutional text, the Framers transferred to the President only a small portion of the power to make war, a power previously exercised entirely by Congress.

The debate goes deeper than this, however. Eugene V. Rostow, one of the most articulate critics of the War Powers Resolution, argued before the Resolution was adopted that "the President's authority goes far beyond that to repel sudden attacks." ${ }^{\text {66 }}$ Historical practice, Rostow insisted, "offers no sharp and formal hines." For Rostow, a proper understanding of the history indicated that

\footnotetext{
40 Emerson, supra note 3, at 209, 212.

11 Id. at 211-13.

42 See A. Sofaer, supra note 4. A particularly provocative reaction to the Sofaer book, by an author who would plainly have preferred a different construction of the history, is Berger, War, Foreign Affairs, and Executive Secrecy, 72 Nw. U.L. Rev. 309 (1977).

is A. Sofaer, supra note 4 , at 3 . Sofaer concludes that the best reading makes the President as Commander in Chief an "agent of the legislature." Id.

4 See id. at 38-60.

6 Id. at 31-32.

48 Rostow, supra note 3 , at 865 .

47 Id. at 866.
} 
the warmaking power was to be shared: Congress, through its power over the purse and power to raise armies, possessed adequate authority to prevent any combat it disapproved, but that did not alter the inherent power of the President to commit troops without first seeking approval. ${ }^{48}$

Alexander Bickel, also writing before the Resolution was law, argued that congressional authority was broader than Rostow suggested, that Congress could, if it chose to do so, "prescribe the mission of our troops in the field in accordance with a foreign and war policy of the United States which it is for Congress to set." 49 The President's broad powers to act in time of war, Bickel explained, alleviated the need to develop a national consensus on every tactical issue that might arise, but that, he said, had nothing to do with the ultimate power to control American forces. ${ }^{50}$ Bickel conceded that historical practice had permitted Presidents to commit American forces in the absence of congressional permission, and he did not deny the power of the President to order troops to fight when Congress has not expressed its disapproval. But that expression of disapproval could come at any time; historical practice had not stripped the Congress of that authority. He argued that although the meaning of the Constitution might change over time, it never loses its "essential shape"-and that essential shape vests Congress, not the President, with ultimate authority over the use of American forces. ${ }^{\text {II }}$

This discussion of the prevailing arguments on both sides of the war powers debate simply provides a prologne to the main act, which will shortly be presented. The traditional battle has been fought over the content of this original understanding and over whether congressional limitation on the President's ability to commit troops restores that understanding or does it violence. The upshot of the previous discussion, however, is that evidence concerning the original understanding -if one indeed chooses to put any faith in that means of constitutional adjudication-does not come down firmly on one side or the other. Fortunately, that does not mean the result of the battle must be inconclusive. It is possible to

\footnotetext{
4s Id. at $864-66$.

10 Bickel, supra note 36 , at 145 .

so Id. at $143-44$.

s1 Id. at $140-41$.
} 
place to one side the squabbles over the Framers' intention or the historical practice of the nation and determine the constitutionality of the Resolution through analysis of its place in the system of checks and balances. A proper understanding of that system leads ineluctably to the conclusion that, although the President might have broad authority to commit American forces in the absence of congressional action, Congress nevertheless holds the power to decide when the President's actions slide down the scale from use of troops in time of peace to use of troops in time of war. The War Powers Resolution is no more than a means to accomplish this legitimate end and, as a consequence, any constitutional challenge to its major provisions should fail.

\section{The War Powers Resolution and the System of Checks AND BaLANCES}

\section{A. The System}

It is a serious though frequent error in constitutional argument to treat questions about the relative powers of two branches of the federal government as though the branches interact in a vacuum, devoid of any powers but the one at issue, and uninfluenced by the presence of the third branch of government. All too often, courts as well as commentators attack these questions by looking only to the language of the constitutional clause thought to be most relevant and that clause's history, and stopping then and there, announcing that the answer has been found. ${ }^{52}$ Although the language of the Constitution is obviously the most important element in any analysis, and the history of the drafting and ratification process may also have a role to play, ${ }^{53}$ to look no further is a serious mistake.

The Constitution does not merely set forth a list of the checks and balances that each branch may use to rein in the other two; it creates a system of checks and balances within which all three branches interact. ${ }^{54}$ Whenever one branch of the government ac-

\footnotetext{
52 For a more detailed critique of this approach, see Brest, supra note 39, at 205-24.

s3 But not so great a role that it takes on more importance than the test. See Laycock, Taking Constitutions Seriously: A Theory of Judicial Review (Book Review), 59 Tex. L. Rev. 343, 351-52 (1981).

st This approach is of course inspired by the work of Charles Black. See C. Black, Structure and Relationship in Constitutional Law (1969); Black, The Working Balance of the American Pohtical Departments, 1 Hastings Const. L.Q. 13 (1974).
} 
cuses another of intruding on the prerogatives of the first, the proper inquiry is how the challenged action fits into that system. ${ }^{\mathrm{ss}}$ It is not sufficient to say, "There is no evidence that the Framers intended for Congress to do $X$, and therefore the President wins." A proper rejection would be of this type: "Should Congress be permitted to do $X$, the delicate balance of power among the three branches of government will be upset." That may seem little more than a subtle shift in emphasis, and it is all of that; but even though subtle, the shift is of critical importance in analyzing questions arising under the system of checks and balances. In the first case, the inquiry is only into the cold language and history, and the relationship between two branches of government; in the second, the inquiry focuses on the federal government as a whole.

A good example is the Supreme Court's recent decision in Nixon $v$. Fitzgerald. ${ }^{56}$ There a slender majority of the Justices ruled that a former President of the United States may not be held liable for civil damages for abusing the powers of his office. To some extent, the Court attacked the question according to the first model, examining only the role and powers of the President. ${ }^{57}$ This, however, was a fruitless approach. As I have argued in more detail elsewhere, the ruling makes sense only when the President is considered in relation to each of the other branches of government. ${ }^{58}$ Then one discovers that the plaintiff was really asking the courts - the judicial branch-to imply a right to sue for damages for presidential misconduct. The plaintiff in Fitzgerald could not win unless the courts were willing to create a new remedy-one not contemplated in the system of checks and balances-for stemming abuses in another branch. The explanation for presidential "immunity" is thus not that "the Framers said so" or "the Constitution says so." Rather, the explanation is that by creating a new remedy the courts would have upset a system fully adequate in itself to deal with executive malefaction. ${ }^{58}$

ss For a more detailed elucidation of this point, see Carter, The Political Aspects of Judicial Power: Some Notes on the Presidential Immunity Decision, 131 U. Pa. L. Rev.

(forthcoming 1983).

se 457 U.S. 731 (1982).

57 See id. at 748-57.

so See Carter, supra note 55.

so Id. See also Black, supra note 54, at 15 ("The powers of Congress are adequate to the control of every national interest of any importance, including all those with which the Pres- 
Another good example of the operation of the system of checks and balances is provided by the Supreme Court's decision late last Term in Immigration and Naturalization Service v. Chadha. ${ }^{60}$ In Chadha, the Justices ruled unconstitutional the legislative veto, at least to the extent that it gave Congress a voice in policymaking without its having to exercise legislative powers. There again, the Court's opinion mostly took the easy way out, concluding that, no matter how one reads article I and its history, the legislative veto is not authorized. ${ }^{61} \mathrm{~A}$ better approach would have been to assess the legislative veto as a part of the system of checks and balances. An approach of that kind would have yielded the same result, but the analysis would have been somewhat different. ${ }^{62}$ The main difference would have been the acknowledgment as an essential part of the decision that Congress is adequately equipped to control the executive branch's deployment of its powers without resort to this extraordinary device. ${ }^{63}$ Mere convenience is not an argument for constitutional validity-at least it is not a good argument-and there is no doctrine permitting subversion of the Constitution in the guise of saving it. ${ }^{64}$

The system of checks and balances should be viewed as dynamic, as constantly in flux. What matters most is that the balance of power among the three branches remain sufficient to check and punish any abuses by any one of them; the precise disposition of authority is subject to change. But the changes do not alter the balance; as Bickel pointed out, the Constitution does not lose its essential shape. ${ }^{65}$ The changes simply reflect exercises of the powers the document grants each branch, although those exercises are now performed in a world quite different from the one in which the powers were first divided. Thus, the apparent rise of judicial activism does not represent a change in the type of power that the

ident might, by piling inference on inference, be thought to be entrusted.").

6o 103 S. Ct. 2764 (1983).

61 Id. at 2781-88.

63 See Carter, supra note 55.

os This would not have been quite dispositive. One question is whether Congress is otherwise adequately equipped; another is whether the Constitution elsewhere grants Congress this authority. See infra text accompanying notes 74-78, 128-39.

ot See Carter, supra note 55. See also Chadha, 103 S. Ct. 2764, 2780-81 (1983) ("[T]he fact that a given law or procedure is efficient, convenient, and useful in facilitating functions of government, standing alone, will not save it if it is contrary to the Constitution.").

${ }^{8 s}$ Bickel, supra note 36 , at $140-41$. 
courts are exercising; it represents a change in the nature of the cases that the courts must decide in the modern world. What matters in this and other cases is only that the branches use their traditional powers, albeit in new ways. The balance of power is upset when the branches presume to use new ones, as the Congress did with the legislative veto.

Once one accepts the image of the system of checks and balances as dynamic rather than static, a question arises as to just how fluid the system can possibly be. It is easy to say that "everything is political," but that might imply that no attempts by one branch to control or frustrate another are unconstitutional, and that all that really matters is the degree of political power that one branch can muster as "authority" for action. In this view, disputes between the President and the Congress would all be political questions. Such an approach is not without its supporters. ${ }^{66}$ Indeed, Jesse Choper has devoted much of his recent book to an argument that, at least with respect to those clashes, pohtical power is all that really matters. ${ }^{67}$

But there is no need to go so far. Even in a fluid system, the Constitution should be read to place real limits on what each branch can do to control the others. For the purposes of this essay, the most important limitation is the one just mentioned: when one branch seeks to rein in another, the first must be applying a power actually granted to it by the Constitution. When the first branch acts instead by creating an additional "fresh" check on the second, then the first is claiming a right to decide when the time has come to upset the balance in pursuit of some higher goal. This claim ignores the fact that the constitutional balance of power among the three branches is delicately crafted, and thus the use of fresh

something of the flavor of this argument is captured by Justice Rehnquist in his plurality opinion in Goldwater v. Carter, 444 U.S. 996 (1979). There the Court dismissed an action hy members of Congress seeking to set aside President Carter's unilateral abrogation of a mutual defense treaty with Taiwan. The members of Congress claimed that because treaties can only be made with the advice and consent of the Senate, that advice and consent is also necessary for their termination. But four Justices responded that the dispute "must surely be controlled by political standards" because it was "a dispute between coequal branches of our government, each of which has resources available to protect and assert its interests, resources not available to private litigants outside the judicial forum." Id. at 1003-04 (Rehnquist, J., concurring in judgment).

67 See J. Choper, Judicial Review and the National Pohtical Process 263, 315-79 (1980) (developing the "Separation Proposal"). 
checks, in the service of whatever cause, can only destroy that balance in the long run. The use of those fresh checks must be forbidden by the system of checks and balances, which permits only those checks that do not work to frustrate the system itself. ${ }^{68}$

\section{B. The Resolution in the System}

An analysis of the place of the War Powers Resolution in the system of checks and balances must confront two questions: First, does the Resolution represent a prohibited "fresh check" on the executive branch? Second, is the Resolution so intrusive into the affairs of the executive branch that it upsets the delicate balance of powers among the three branches?

\section{Congressional Authority}

New or fresh checks by one branch on the actions of another are prohibited when the first is seeking to control the second through exercise of some power not granted to it by the Constitution. Thus, if the War Powers Resolution is constitutional, it must be traced to some grant of authority in the Constitution.

Supporters of the Resolution usually trace it to the express grant to Congress in article I, section 8, of the power "To declare War." The power to declare war, they assert, includes the power to control all missions of American troops abroad, except when there exists a need to repel a "sudden attack" against the United States." This assertion always leads into a discussion of the original understanding and the historical practice-a dispute in which, as I suggested earlier, no one is likely to prevail. That the evidence seems to cut both ways ought to signal to proponents of this broad congressional authority that they are fighting the wrong battle. They are not wrong in using the power to declare war to support the constitutionality of the War Powers Resolution; they are wrong only in the way in which they use it.

The War Powers Resolution is constitutional because its terms constitute a congressional definition of the word "war" as it is

6s Were this not true, the slippery slope and policing problems would be insurmountable. See also Carter, supra note 55.

os U.S. Const. art. I, \& 8, cl. 11.

${ }^{70}$ See, e.g., Berger, supra note 7, at 41-45; Eagleton, supra note 36, at 6; Lofgren, supra note 4 , at 679 . See also supra text accompanying notes $42-45$. 
used in article I. By enacting the Resolution, Congress was saying to the President: "This is your sphere and this is our sphere. When you leave your sphere and enter ours, you must come to us for permission."

The importance of this definition is most apparent when measured against the judicial refusal to become involved in defining either the word "war" or the limits of the congressional war power. ${ }^{71}$ This judicial hesitation is perfectly sensible: it is difficult to imagine what standards a court could develop for saying that one conflict is a "war" in the article I sense, while another is merely a "repulsion of a threat" that the President can undertake on his own. ${ }^{22}$ That a court is unable or unwilling to develop standards, however, does not mean that Congress cannot do so. After all, it is to Congress that the power to declare war is granted. Unless Congress is also capable of deciding when the thing in which the President has involved the nation deserves the appellation "war," it is difficult to see what good that power can possibly be. It is plain that the congressional power to declare war was meant as one of several checks on the President's authority over the use of American military forces. ${ }^{73}$ If the President can avoid the force of that check merely by declining to seek a declaration of war, then it is a check of no real force.

Naturally, as opponents of the Resolution frequently poimt out, the Constitution contains a number of other congressional powers

71 See, e.g., Massachusetts v. Laird, 400 U.S. 886 (1970); Mora v. McNamara, 389 U.S. 934, denying cert. to 387 F.2d 862 (D.C. Cir. 1967).

72 Even if a court were willing to grapple with questions of this kind, it is not clear as a practical matter either where the court would look for standards or how it would enforce its judgment. See Ehrlich, The Legal Process in Foreign Affairs: Military Intervention-A Testing Case, 27 Stan. L. Rev. 637, 646-47 (1975). But see Massachusetts v. Laird, 400 U.S. at 891-900 (Douglas, J., dissenting from order denying leave to file complaint) (arguing that controversy over whether Vietnam conflict is a war presents justiciable question); Firmage, The War Powers and the Political Question Doctrine, 49 U. Colo. L. Rev. 65, 98-99 (1977) (arguing that War Powers Resolution itself provides judicially manageable standards for determining whether the President is exceeding his power).

is See The Federalist No. 69, at 446 (A. Hamilton) (B. Wright ed. 1961). For background discussions of the views of the Framers on the need for a shared warmaking power, see, e.g., Berger, supra note 7, at 34-47 (arguing that President's share of the power was intended to be a small one); Friedman, supra note 7, at 218-23 (contending that President could use troops on his own initiative only to repel attacks); Lofgren, supra note 4, at 678-88 (concluding that broad statements by Framers about use of troops were with reference to power of national government in general, not of President in particular; presidential power was narrow). 
that could conceivably be used to restrain a President intent on fighting when Congress wanted him to stop. ${ }^{74}$ These include most prominently the congressional power over the military budget and the congressional authority to raise armies. ${ }^{75}$ Those checks have an undeniable force of their own. But that hardly matters, because the Constitution includes the power to declare war as well. Ordinarily, the existence of other means, clearly indicated in the Constitution, by which Congress can accomplish its ends ought to be sufficient to strike down a fresh check that Congress develops. ${ }^{76}$ But that rule should not apply when the apparent fresh check is itself based on an explicit grant of authority. To say that Congress must resort to its other powers to protect its power to declare war is to say that the power to declare war is itself a nullity, conferring on the Congress no real authority of any kind. Opponents of the Resolution sometimes seem to be making something very close to this argument, ${ }^{77}$ but it seems an unhealthy precedent to construe out of existence any provision of the Constitution..$^{78}$

\section{Intrusiveness}

Even if it is conceded that Congress indeed possesses some authority to define the substantive content of its war powers, that concession does not by itself suggest where the limits on that definitional authority may lie. The major limitation, however, ought to be obvious: in this area as in others, the Congress may not promulgate a rule that intrudes too deeply into the affairs of the executive branch.

To determine whether the War Powers Resolution does intrude

\footnotetext{
74 See, e.g., Rostow, supra note 3 , at 850 .

73 U.S. Const. art. I, § 8, cls. 12-16. But see Emerson, supra note 3, at 213 ("If the Constitution does give the President authority to protect American rights and interests abroad, Congress cannot by a mere appropriation rider redefine the allotment of powers made by the framers.").

${ }^{76}$ This is the principle that best explains the Supreme Court's decision in Chadha, $103 \mathrm{~S}$. Ct. 2764 (1983). See supra text accompanying notes 60-64.

77 I refer here to the distinction opponents sometimes draw between "offensive" wars and wars of other kinds. See supra note 3 and accompanying text. The Supreme Court's opinion in The Prize Cases, 67 U.S. (2 Black) 635 (1863), also has some of this flavor, although to be sure, it is not a very strong precedent for this point. See infra text accompanying notes 84-

${ }^{78}$ Cf. J. Ely, Democracy and Distrust $38-41$ (1980) (similar argument on behalf of ninth amendment).
} 88. 
too deeply, it is first necessary to identify the legitimate executive prerogative that the Congress might have infringed. Opponents of the War Powers Resolution make a serious argument on intrusiveness regarding only one executive prerogative. That is the President's power as "Commander in Chief of the Army and Navy of the United States," wh which is said to encompass a "traditional" or "historical" authority to deploy troops outside the United States in defense of some version of the nation's vital interests. ${ }^{80}$

It is not easy to say that authority of this kind does not exist; but it is also not easy to say that it does exist. Certainly the language of the Commander-in-Chief clause sheds little hight. The clause states only that the President "shall be" the Commander in Chief. It is perhaps most remarkable for what it does not say: it does not say when, it does not say where, it does not say how. The clause does not, in short, yield a single clue on whether the power it grants is subject to congressional control or direction. ${ }^{81}$ The historical evidence on "the original understanding" concerning the Commander-in-Chief clause can safely be described as ambiguous, in the sense that it is unhikely to convince anyone who has not yet taken sides. ${ }^{82}$ In short, if support is to be found for the argument that the War Powers Resolution intrudes on a traditional presidential power to deploy troops in the face of legislative opposition, that support must flow from some source other than the language or history of the Constitution itself.

70 U.S. Const. art. II, § 2.

so See, e.g., Emerson, supra note 3, at 195-209; Rostow, supra noto 3, at 851-70.

-1 Raoul Berger has pointed out that in $\mathbf{1 7 8 3}$ the Continental Congress ordered General Washington to undertake certain actions. Berger, supra note 7 , at 37 . This argument is apparently intended to imply that the President as Commander in Chief is subject to congressional direction in the same fashion as any other general. There are at least two problems with this particular "facial construction" of the Commander-in-Chief clause. First, however small the shice of war power is that the Framers intended to transfer to the President through the clause, there is hittle question but that they intended to insulate day-to-day conduct of authorized military operations from legislative direction. See, e.g., 1 Records, supra note 38, at 292 (Hamilton); E. Corwin, The President: Office and Powers 1787-1957, at 228 (4th ed. 1957). Second, it is not clear whether Congress can in fact issue direct orders to a military commander. Cf. A. Sofaer, supra note 4, at 147-64 (discussing historical evidence on day-to-day congressional control).

82 Compare Emerson, supra note 3, at 201-09 (stating history makes plam that broad discretion in use of armed forces was intended) with Berger, supra note 7, at 36-39 (stating history makes plain that President was to be no more than the highest general). See generally supra notes $36-51$ and accompanying text. 
Certainly the judicial precedents are thin. Although any number of decided cases make some reference to the Commander-in-Chief clause, it does not appear that the Supreme Court has ever been asked to decide what authority that clause grants the President to act when Congress seeks to make the President's actions illegal. ${ }^{83}$ For example, opponents of the War Powers Resolution often make reference to the Prize Cases, ${ }^{84}$ in which a narrowly divided Supreme Court sustained Union seizures of ships trading with the Confederacy. The seizures resulted from the blockade of the southern states ordered by President Lincoln. The question was whether the President had authority to order the blockade in the absence of a congressional declaration of war. In an equivocal opinion, the majority ruled that the President had inherent authority as Commander in Chief to quell armed insurrection ${ }^{85}$ or, if he lacked that power, that Congress had ratified the blockade order by subsequent legislation. ${ }^{88}$

The strongest argument that can be based on the Prize Cases would hold only that the President enjoys some degree of inherent authority to defend the United States against "sudden attack"-but supporters of the War Powers Resolution willingly concede this much. ${ }^{87}$ Moreover, because the Court's opinion is so equivocal, it may stand for a good deal less than this: if congressional ratification explains the result, then the decision in the

8s The Court has been quite explicit in its avoidance of this issue. For example, when the Court in the celebrated case of Ex parte Quirin, 317 U.S. 1 (1942), sustained a presidential proclamation that German saboteurs caught in the United States be tried in inilitary rather than civilian courts, the Court explained: "It is unnecessary for present purposes to determine to what extent the President as Commander in Chief has constitutional power to create military commissions without the support of congressional legislation. For here Congress has authorized trial of offenses against the law of war before such commissions." Id. at 29. In a later case dealing with the power of the President to constitute military tribunals beyond those authorized by Congress, the Justices sustained his actions "[i]n the absence of attempts by Congress to limit the President's power." Madsen v. Kimsella, 343 U.S. 341, 348 (1952). In an earlier case, the Court upheld the President's restriction of commercial intercourse with the "enemy" because it was done pursuant to congressional delegation to the Commander in Chief. Hamilton v. Dillin, 88 U.S. (21 Wall.) 73, 92 (1874). See also Santiago v. Nogueras, 214 U.S. 260, 265 (1909) (Commander in Chief may administer conquered territory until Congress acts to end military government); Fleming v. Page, 50 U.S. (9 How.) 603, 614-15 (1850) (similar rule).

${ }^{84} 67$ U.S. (2 Black) 635 (1862).

ss Id. at 666-70.

${ }^{86}$ Id. at 670-71.

${ }^{87}$ See supra note 70 (citing sources). 
Prize Cases says no more than that presidential troop commitments are permitted if Congress subsequently gives consent. ${ }^{88}$

Similarly, Martin v. Mott, ${ }^{89}$ although sometimes cited to support the notion of a broad presidential war power, is actually quite to the contrary. In Mott, the Justices sustained the delegation by Congress to the President of the authority to call forth the militia to repel invasion. In the course of his opinion for the Court, Justice Story wrote:

If it be a limited power, the question arises, by whom is the exigency to be judged of and decided? . . . We are all of the opinion, that the authority to decide whether the exigency has arisen, belongs exclusively to the President, and that his decision is conclusive upon all other persons.90

But the Mott language, like that of the Prize Cases, stands for a good deal less than the proposition for which it is usually cited. In Mott, the only power whose locus of decision the Court had to find was "a limited power, confined to cases of actual invasion, or of imminent danger of invasion," the War Powers Resolution concede to the President. The power was not, moreover, inherent in the executive branch; on the contrary, it was a power "confided by Congress to the President." Thus, the rule of Martin $v$. Mott must be something like this: When Congress delegates to the President the authority to call the militia into service to repel invasion, only the President can judge when an invasion is occurring or about to occur. Nothing in the War Powers Resolution vitiates this rule.

Opponents of the War Powers Resolution do not rest their arguments only on decided cases. They also refer to consistent historical practice. ${ }^{\text {ss }}$ Certainly their evidence is strong. It cannot be de-

ss The President's authority to repel sudden attacks might be explained this way too: "No doubt the consent of Congress to war in the event of invasion or attack could be assumed." L. Henkin, supra note 4, at 305 n.38.

25 U.S. (12 Wheat.) 19 (1827).

90 Id. at 29-30.

91 Id. at 29.

22 Id. Moreover, the Court explained, the President's judgment was final only because "[t]he law does not provide for any appeal." Id. at 31. That statement hardly supports the conclusion that Martin v. Mott broadly construed the President's inherent authority as Commander in Chief.

os See supra note 80 (citing sources). 
nied that Presidents have long assumed the authority to commit American forces on their own initiative and that Congress has rarely done anything to interfere..$^{94}$ But that need not be viewed as stating a rule; it may only be a statement of a problem. For unless this power has always rested with the executive branch under the constitutional scheme, all that has permitted Presidents to act in this fashion has been the acquiescence of Congress. ${ }^{95}$ Such congressional acquiescence might make the President's unencumbered action presumptively valid, but it says nothing about the power of Congress to revoke its permission.

The Steel Seizure Case ${ }^{96}$ and the Iranian Assets Case $^{97}$ are instructive on this point. Both cases involved claims of "inherent" presidential authority to act. In Steel Seizure, President Truman claimed the right to seize the nation's steel mills, relying in part on the Commander-in-Chief clause. The Court rejected the President's claim, but Justice Frankfurter, in his concurring opinion, suggested that "a systematic, unbroken executive practice, long pursued to the knowledge of Congress and never before questioned ... may be treated as a gloss on 'executive Power' vested in the President" by article II. ${ }^{98}$ The Court majority adopted the Frankfurter test to uphold challenged presidential authority in the Iranian Assets Case, ${ }^{99}$ a case involving President Carter's revocation of licenses authorizing judicial proceedings against Iran. But the Iranian Assets Case involved a situation in which congressional acquiescence was continuing. ${ }^{100}$ In Steel Seizure, the circumstance was quite different, and Justice Frankfurter concluded that through its passage of the Taft-Hartley Act in 1947, Congress had effectively withdrawn whatever acquiescence might have supported the President's actions. ${ }^{101}$

\footnotetext{
94 That is not the same as saying, however, that members of Congress have raised no objection to the President's actions. For an interesting compendium of congressional objections, see Allman, The Doctrine That Never Was, Harper's, Jan. 1984, at 14.

os I choose the word "acquiescence" advisedly, to avoid two other possible descriptions: "consent," whicb might imply an affirmative action by the Congress, and "failure to act," which might imply the rejection of a proposal for action.

*6 Youngstown Sheet \& Tube Co. v. Sawyer, 343 U.S. 579 (1952).

97 Dames \& Moore v. Regan, 453 U.S. 654 (1981).

${ }^{98} 343$ U.S. at 610-11 (Frankfurter, J., concurring).

99 453 U.S. at $678-88$.

100 Id. at $687-88$.

${ }^{101} 343$ U.S. at 603.
} 
The proposition that Congress can withdraw its acquiescence is hardly a novel one. It represents what I take to be the thrust of Alexander Bickel's critique of the argument for imphed executive war authority. ${ }^{102}$ On more than one occasion, the Justices have sustained over direct constitutional assault congressional efforts to limit the ability of the President to continue to do what he previously had "always done." For example, until the 1930's, it was always assumed that the President had the power to fire any employee of the executive branch. ${ }^{103}$ But in Humphrey's Executor $v$. United States, ${ }^{104}$ the Supreme Court ruled that Congress could restrict that authority through the device of granting some of what might otherwise have been considered executive authority to individuals "other than executive officers." 10 Similarly, until the Watergate scandals erupted, Presidents had traditionally been entitled to make the final decisions on disposition of their personal papers and effects when they left office. Yet in Nixon v. Administrator of General Services, ${ }^{106}$ the Court ruled that Congress possessed the authority to alter that tradition. ${ }^{107}$ Even under the Commander-in-Chief clause, the Court has in the past followed similar reasoning. Thus, although the Court has held that the President, acting as Commander in Chief, may establish military tribunals and provide for the governance of occupied territory, ${ }^{108}$ the Justices have been at pains to note that the President may do so only until Congress legislates a contrary intention. ${ }^{109}$

\footnotetext{
${ }^{202}$ See generally Bickel, supra note 36 . Cf. Black, supra note 54, at 20 ("The one fundamental error is that of supposing that the modern expansion of presidential power is hased on the Constitution by itself, and is hence inaccessible as a matter of law to congressional correction.")

${ }^{103}$ Myers v. United States, 272 U.S. 52 (1926), discussed infra note 111.

104295 U.S. 602 (1935).

${ }^{105}$ Id. at 631 . See Wiener v. United States, 357 U.S. 349, 353 (1958) (elaborating on this theme).

${ }^{108} 433$ U.S. 425 (1977).

107 Id. at $441-55$.

${ }^{108}$ See, e.g., Madsen v. Kinsella, 343 U.S. 341 (1952); Santiago v. Nogueras, 214 U.S. 260 (1909); Dooley v. United States, 182 U.S. 222 (1901).

${ }^{100}$ For example, in Santiago v. Nogueras, 214 U.S. 260 (1909), the Court had this to say of the military government on Puerto Rico, authorized by the President:

The President might have dissolved it by withdrawing the army and navy officers who administered it, but he did not do so. Congress could have put an end to it, but that was not done. The right inference from the inaction of both is, that it was meant to be continued until it had been legislatively changed.

Id. at 265 (quoting Cross v. Harrison, 57 U.S. (16 How.) 164, 193 (1853)) (emphasis added).
} 
All these cases stand quite plainly for the proposition that the President can exercise a purportedly inherent power if Congress has historically acquiesced and if Congress does not try to stop him. If Congress does try to stop him, then by definition it is no longer acquiescing. In a fluid and dynamic system of checks and balances, this is the only conclusion that makes sense. It is surely not the case that all that is, is constitutional, so absent some constitutional equivalent of adverse possession, what Congress has given, Congress can also take back. ${ }^{110}$

Even if one beheves that the President possesses certain "inherent" powers, the Supreme Court has almost never struck down a congressional enactment for intruding into the sphere of one of those powers, except when the presidential power in question is granted explicitly and unambiguously in the Constitution. ${ }^{111}$ In

Cf. Dooley v. United States, 182 U.S. 222, 236 (1901) (Commander in Chief's temporary power to govern ends when Congress acts).

110 Thus, in the Iranian Assets Case, even as the Court sustained the President's exercise of the power to suspend claims pending against the Iranian government, the Justices warned: "Past practice does not, by itself, create power . . . ." 453 U.S. at 686 (emphasis added). The President's action was sustained not because he was inherently empowered to take it, but rather because "Congress may be considered to have consented to the President's action." Id.

One advocate of strong inherent presidential war authority has argued that in fact the powers do shift because "constitutional policy for ensuing epochs is not congealed in the mold of 1787 referants [sic]." Ratner, The Coordinated Warmaking Power-Legislative, Executive, and Judicial Roles, 44 S. Cal. L. Rev. 461, 467 (1971). This has led one critic to respond sharply: "[I]t is a marvelous non-sequitur that . . . the servants of the people may informally amend the Constitution without consulting them." Berger, supra note 7, at 56 . Berger added: "[T] $T$ here is no room for a take-over by the President of powers that were defined to him [in the 1787 Constitution] and, as our own times demonstrate, denied with good reason." Id. at 57. Ratner and Berger may both be a bit right and a bit wrong. Although historical practice may not change the meaning of the Constitution, but see Munzer \& Nickel, Does the Constitution Mean What It Always Meant?, 77 Colum. L. Rev. 1029 (1977), it will certainly change the year-to-year working balance of powers. Obviously, some of these changes will be acceptable, and others will not, depending on where one draws the line-and that is what the whole fight over the War Powers Resolution is about. The thesis presented in this essay is that because only the working balance, and not the Constitution itself, has been changed, Congress may change the balance again by reacquiring what it has lost.

${ }^{111}$ The case coming closest to an exception is Myers v. United States, 272 U.S. 52 (1926). In Myers, the Court held unconstitutional a congressional statute protecting certain postmasters from arbitrary presidential removal. The decision was based on the "reasonable implication" that the President possessed the power to choose those who would execute the laws. Id. at 161-64. But as the decisions in Humphrey's Executor v. United States, 295 U.S. 602 (1935), and Wiener v. United States, 357 U.S. 349 (1958), make clear, Myers is so narrowly himited that it can be circumvented by a proper congressional definition of the nature 
Buckley $v$. Valeo, ${ }^{112}$ to take just one example, the Justices ruled that Congress was trying to do something-appoint officers of the United States-that the Constitution by its terms empowered only the President to do. ${ }^{113}$ Decision on that point was not difficult because the President's authority to appoint all officers of the United States appears plainly on the face of the document. ${ }^{114}$ Whatever might be said about the Commander-in-Chief clause, it certainly grants no power in terms as clear and unambiguous terms as those of the appointment clause.

The "inherent" powers to which opponents of the War Powers Resolution make reference are really of another kind altogether; they are powers thought to be "inherent" because the President has historically exercised them. But they are powers the President has historically exercised in the absence of any congressional objection. In that sense, whether the powers are denominated "inherent" or something else is surely a non sequitur. As the decided cases make clear, mere historical acquiescence by Congress in the President's exercise of a particular power does not by itself prove that Congress lacks the authority to limit the exercise of that power when it gathers the wisdom and courage to do so. Justice Jackson's Steel Seizure concurrence carried the warning that "only Congress itself can prevent power from slipping through its fingers,"11s and that warning presupposes what is argued here: that Congress, if it so chooses, can regain power lost to the executive branch through its own inaction. If the Congress does not act when conditions demand action, then the President will exercise power because power must be exercised. But the fact that the President exercises a power when Congress does not, does not render that power one that is "inherent" in the executive. At best, the power is "inherent" in the government of the United States. Thus, the argument that Presidents have "always" controlled troops without congressional interference proves no more than perhaps its own premise: that Presidents have always done this. In particular, that

and duties of the official in question.

112424 U.S. 1 (1976) (per curiam).

13s Id. at 126 (stating "any appointee exercising significant authority pursuant to the laws of the United States is an 'Officer of the United States'" and must be appointed pursuant to the provisions of article II).

114 See U.S. Const. art. II, § 2, cl. 2.

115343 U.S. at 654 (Jackson, J., concurring). 
historical conclusion makes no statement at all about congressional authority to alter that long-standing state of affairs. ${ }^{116}$

Naturally, the mere fact that Congress is in some cases entitled to take back or limit the exercise of powers previously thought to rest in the executive branch does not mean that Congress can always do so. However, the conclusion that Congress lacks the power must be based on something other than the assertion that the President has "always" done what Congress now seeks to forbid. Yet, that argument, which can be posed against virtually any congressional enactment restricting the freedom of the President, is the only one seriously pressed by the opponents of the War Powers Resolution.

\section{Reasonableness}

If claims of intrusiveness raise no bar to congressional definition of its own war power, then the only remaining substantive limit would seem to be the one the Court mentions intermittently in its separation of powers jurisprudence: the definition must be "reasonable."117 Quite probably, when the Court suggests that restrictions on the freedom of the executive branch must be reasonable, it is imposing on Congress only the usual minimum rationality test said to be embodied in the due process clause of the fifth amendment. ${ }^{118}$ As a rule, a test of this nature has no bite when applied to

\footnotetext{
118 Failure to see this distinction accounts for occasional citation to the line of cases beginning with United States v. Midwest Oil Co., 236 U.S. 459 (1915), as authority for the proposition that a power can be "transferred" to or "vested" in the executive branch through congressional acquiescence in its exercise. In Midwest Oil, the Court sustained the power of the President, in the absence of express congressional permission, to withdraw public lands from private use. After noting that Presidents had consistently withdrawn lands for more than 80 years, the Justices added: "[T]he long-continued practice, known to and acquiesced in by Congress, would raise a presumption that the withdrawals had been made in pursuance of its consent or of a recognized administrative power of the Executive ... ." Id. at 474. But Midwest Oil had nothing to do with the situation in which Congress seeks to interpose an objection after years of apparent acquiescence. Because Congress made no effort to register an objection, the Midwest Oil case too stands simply for the proposition that the President may act when the Congress does not seek to stop him.

117 The fact that the Court will decree that congressional regulations must be reasonable does not mean that it will decide whether they are in fact reasonable. Compare Dillon v. Gloss, 256 U.S. 368 (1921) (holding Congress may fix "reasonable time" for ratification of proposed constitutional amendment) with Coleman v. Miller, 307 U.S. 433, 457-60 (1939) (Black, J., concurring) (question whether time is in fact reasonable is nonjusticiable political question).

118 See, e.g., United States Dep't of Agric. v. Moreno, 413 U.S. 528 (1973). This equal
} 
federal legislation. ${ }^{119}$ It makes sense, however, to assume at least for the sake of argument that the test has some small amount of bite when applied to legislation said to violate the separation of powers principle.

Without attempting a formal definition of this "heightened" requirement of reasonableness-an attempt that would be beyond the scope of this small article-I will observe that at the very least, the shoe should be on the other foot. That is, it should be incumbent upon the opponents of the Resolution to explain why its definitional provisions are unreasonable. Once the conflict is viewed that way, it should be evident that, unless one begins with the premise that Congress is without power to act in this area, the restrictions it has placed on the commitment of American forces in the absence of congressional permission are reasonable. The Resolution, with its requirement of congressional permission, comes into effect only when American troops are involved in hostilities, when they are sent into foreign nations while equipped for combat, and when the size of a foreign-based contingent of combat-ready American troops is increased substantially. Moreover, unless Congress acts affirmatively to interpose an objection, the President may keep the troops in action for sixty to ninety days before he is required to withdraw them.

Reasonable people might disagree on whether each of these conditions, if continued for ninety days, represents an exercise of the war power of the United States, but the claim that each of them does represent an exercise of that power hardly seems an unreasonable one to assert. And, of course, if the President wants to keep troops committed for a longer period of time, he can seek congressional permission. If three months are not adequate time for the troops to complete their mission or for the President to justify their deployment, then it hardly seems unreasonable for Congress to say that they must come home. Unless the President possesses inherent authority to commit troops to combat for more than ninety days in the face of congressional disapproval, the judg-

protection component, the Court has explained, possesses essentially the same substantive content as the fourteenth amendment's equal protection clause. See Bolling v. Sharpe, 347 U.S. 497 (1954).

119 For a sample of just how little bite such a test contains, see United States R.R. Retirement Bd. v. Fritz, 449 U.S. 166 (1980). Indeed, the test contains so little bite that it is almost beneath the dignity of a serious scholar to discuss it. 
ment on reasonableness is an easy one to make. Because the President does not possess inherent authority of this kind, the War Powers Resolution must be considered a proper exercise by the Congress of constitutionally granted authority.

If the restrictions contained in the War Powers Resolution are neither intrusive nor unreasonable, then an interesting question arises. Suppose a foreign power invaded the territory of the United States, and the President, relying on his inherent "sudden attack" authority, used force to repel that invasion. Could the Congress require him to stop, even if that would mean letting the invaders triumph? It is tempting and easy to say, "No, that would clearly be unreasonable," and perhaps it would be. But the result is not so clear. Congress would be remarkably foolish, even unpatriotic, ${ }^{120}$ to take this step, and it probably would never happen. ${ }^{121}$ But if the question is one of congressional authority, the Constitution might permit a definition as broad as this one. In a nation governed by a constitution, it is impossible to arrange matters so that the good guys always win. ${ }^{122}$

That understanding perhaps provides an epitaph for the argument that the War Powers Resolution is unconstitutional. In the system of checks and balances, as in other areas of constitutional theory, tlie line between policy that is unwise and policy that is unconstitutional is often difficult to draw. Nevertheless, the guiding principle here as elsewhere ought to be that policy is not unconstitutional merely because it is unwise. ${ }^{123}$

120 The speech and debate clause, however, would probably protect the members from prosecution for treason. See U.S. Const. art. I, § 6, cl. 1 .

${ }^{122}$ Dean Ely is of the view that constitutional theorists may legitimately decline to adapt their theories to hypotheticals that could never happen. See J. Ely, supra note 78, at 183. Most theories, however, are weakest by far at the margin, and often there is no other point of comparison.

122 Nevertheless, most of us indulge a very human urge to try. For a provocative critique, one with which I do not necessarily agree, see Monaghan, Our Perfect Constitution, 56 N.Y.U. L. Rev. 353 (1981).

${ }^{223}$ This line may have been blurred a bit in Professor Rostow's early comment on the War Powers Resolution: "Its passage would be a constitutional disaster, depriving the government of the powers it needs most to safeguard the nation in a dangerous and unstable world." Rostow, supra note 3 , at 836 . Rostow's second clause might be correct, although practice has not demonstrated it. But even if true, it represents at best an argument only that the Resolution is unwise. That the Resolution might be a practical or political disaster does not render it a constitutional disaster. 


\section{The Resolution and Immigration and Naturalization Service v. Chadha}

Even if Congress possesses authority under the Constitution to limit or control the deployment of American forces in combat situations, it may do so only through means that the Constitution permits. Thus, before concluding discussion on the constitutionality of the War Powers Resolution, it is necessary to determine whether its enforcement mechanism has been rendered unconstitutional by the Supreme Court's recent decision in Immigration and Naturalization Service v. Chadha. ${ }^{124}$ In Chadha, the Justices ruled unconstitutional a congressional effort to retain control of delegated power through the device of a legislative veto. ${ }^{125}$ Subsequent summary affirmances have made clear that Chadha was meant to enunciate a broad rule and is not limited to its particular facts. ${ }^{126}$

The War Powers Resolution contains two provisions that might be construed as legislative vetoes. One is the requirement in section 5(b) that the President withdraw American troops if he does not within sixty days receive congressional permission for their deployment. The other is the requirement in section 5(c) that the President withdraw the troops at any time if commanded to do so by a joint resolution of the Congress.

On first reading, section 5(c) would seem to be a classic legislative veto. If constitutional, that section would permit Congress to adopt a resolution requiring the President to do something without giving the President the opportunity to exercise his own veto power under the presentment clause. ${ }^{127}$ That appears to be precisely what the rule of Chadha forbids, and it is not easy to see how section 5(c) can survive.

There is more to section 5(c) than meets the eye, however, and

\footnotetext{
124103 S. Ct. 2764 (1983).

125 The statute at issue in Chadha permitted either house of Congress, by resolution, to invalidate the decision of the Attorney General to permit a deportable alien to stay in the United States. See id. at 2770-72.

${ }^{128}$ See Process Gas Consumers Group v. Consumers Energy Council of Am., 103 S. Ct. 3556 (1983) (affirming judgment on or denying certiorari to eight requests for relief from rulings striking down legislative vetoes).

${ }_{127}$ See U.S. Const. art. I, $\S 7$, cl. 2 (presentment clause). For the Court's explanation of why legislating without complying with this clause is impermissible, see Chadha, $103 \mathrm{~S}$. Ct. at 2780-83 (stating all enactments of positive law must be presented to the President for signature).
} 
an argument is available that might save it. To understand this argument, it is necessary to go back nearly two centuries to the Supreme Court's decision in Hollingsworth v. Virginia. ${ }^{128}$ In $\mathrm{Hol}-$ lingsworth, the Court rejected a contention that the eleventh amendment was invalid because, after being proposed to Congress in a joint resolution, it was never presented to the President for his signature. In a terse footnote, Justice Chase explained,."There can, surely, be no necessity to answer this argument. The negative of the President applies only to the ordinary cases of legislation: $\mathrm{He}$ has nothing to do with the proposition, or adoption, of amendments to the Constitution." ${ }^{129}$ Hollingsworth is not an easy decision to justify, flying as it does in the face of the presentment clause's requirement that "Every Order, Resolution, or Vote to which the Concurrence of the Senate and House of Representatives may be necessary . . . shall be presented to the President" for approval or disapproval. ${ }^{130}$ But the rule of Hollingsworth-that the President plays no formal role in the proposition of constitutional amendments-has become firmly entrenched in our jurisprudence and was even restated by the majority in Chadha. ${ }^{131}$ Thus, even after Chadha, there appear to be two categories of legislation: "ordinary" legislation, which requires presentment to the President, and what might be called "extraordinary" legislation, which does not. Obviously, the problem for those who want to retain Section 5(c) is to show how the joint resolution that provision permits fits into the second category.

The argument from Hollingsworth would run something hike this: A joint resolution commanding the President to bring troops home is not a part of the general article I legislative power, but an exercise instead of an extraordinary legislative power-the specific article I power to vote on whether to go to war. Because the War Powers Resolution defines a state of war-that thing into which the United States cannot enter without congressional permis-

\footnotetext{
1283 U.S. (3 Dall.) 378 (1798).

${ }^{128}$ Id. at $381 \mathrm{n.*}$.

130 U.S. Const. art. I, $\$ 7$ (emphasis added). I am grateful to Charles Black for reminding me of the flat inconsistency hetween the decision in Hollingsworth and the language of the presentment clause. For the purposes of the argument set forth in this section, I assume only arguendo that the case was decided correctly; I would not want to be forced to defend Justice Chase's reasoning were the issue one of first impression.

1s1 See Chadha, 103 S. Ct. at 2786 n.20.
} 
sion-the joint resolution permitted by section $5(\mathrm{c})$ is simply the Congress' way of indicating whether it wishes to extend its permission. This argument turns in part on whether one believes that the President has the right to veto a declaration of war-a point on which no court has ever ruled and on which scholars have divided. ${ }^{132}$ If the President lacks the power to veto a decision to go to war, then the congressional role in exercising its war power is arguably much like its role in exercising its power to propose amendments to the Constitution.

That argument is admittedly a shaky one, for it is a simple matter to find distinctions between the power to propose constitutional amendments and the power to control the President's use of troops. ${ }^{133}$ One distinction is that the amendment power is found in article $\mathrm{V}$, not in article I. That is not a helpful distinction, however, because it is plainly wrong to suggest that only article I legislation requires presentment. The federal courts, for example, are organized pursuant to congressional authority under article III, not article I, but no one would suggest that as a result presentment is not required. A second, stronger distinction is that the war power, whatever its contours, is just one of a number of legislative powers set forth in article I, section 8 , and that all the other powers on the list appear clearly subject to presentment. Pure formalism and close attention to constitutional structure would suggest that that argument refutes the claim that the war power is an extraordinary one, but, in fact, the refutation is not so clear. The system of checks and balances might require a sharing of the war power in a

132 See L. Henkin, supra note 4, at 32-33, 295 n.5 (citing sources). For a rather complex theory on which war measures the President can veto, see Ratner, supra note 110, at 489:

The President may veto a congressional declaration of hostilities or a later congressional termination of declared hostilities but not a congressional veto of hostilities independently authorized by him. Adjudication is required to resolve the constitutional impasse created when a president vetoes a congressional resolution that corrects his interpretation of a hostilities declaration.

1ss One of those distinctions is not that, although the President plays no formal role in the constitutional amendment process, he does ordinarily play a role in the declaration of war because he generally requests Congress to act. This in fact is one reason that the question whether the President's consent is required has never been raised in practice. See $L$. Henkin, supra note 4, at 295 n.5. But this does not by itself render the declaration of war an exercise of an "ordinary" legislative power. After all, a President may also request Congress to vote on a constitutional amendment, but that does not mean the presentment clause applies. See Hollingsworth v. Virginia, 3 U.S. (3 Dall.) 378 (1798), discussed supra text accompanying notes 128-29. 
way that it does not require sharing of other powers. ${ }^{134}$ More to the point, as Hollingsworth makes clear, formalism alone does not tell which powers are ordinary and which are extraordinary. Just what the test should be is not at all clear; but for just that reason, it is not easy to predict whether a court would accept the argument that the war power is special. ${ }^{138}$ The third and most powerful distinction is that when Congress proposes constitutional amendments, it is merely setting in motion a process that might ultimately lead to new law, but when it invokes the joint resolution permitted by section $5(\mathrm{c})$, it is instantly creating new law. ${ }^{136}$ There is no good answer to this, ${ }^{137}$ other than to suggest that it does, in a sense, beg the question. Perhaps the joint resolution creates new law; but it may also be an exercise of extraordinary legislative authority, not creating new law but confining the President to the requisites of the old. The strongest justification for the Chadha result is, after all, that the legislative veto constitutes a fresh check on presidential action. ${ }^{138}$ But because the War Powers Resolution is not itself forbidden as a fresh check (because of the "specialness" of the shared warmaking authority), ${ }^{139}$ the enforcement mechanism created by section 5(c) might also not be a fresh check, and for much the same reason.

${ }^{134}$ As the United States Court of Appeals for the District of Columbia noted (in dictum) in striking down a legislative veto, "[T] he foreign affairs veto presents unique problems since in that context there is the additional question whether Congress or the President or both have the inherent power to act." Consumer Energy Council of Am. v. FERC, 673 F.2d 425, 459 (D.C. Cir. 1982), aff'd mem. sub nom. Process Gas Consumers Group v. Consumers Energy Council of Am., 103 S. Ct. 3556 (1983).

${ }^{135}$ This approach to analysis is inspired by Holmes' oft-quoted dictum, "The prophecies of what the courts will do in fact, and nothing more pretentious, are what I mean by the law." O.W. Holmes, The Path of the Law, in Collected Legal Papers 167, 173 (1920).

${ }^{138}$ The majority in Chadha stated that the veto there in issue "was essentially legislative in purpose and effect" because it "had the purpose and effect of altering the legal rights, duties, and relations of persons, including the Attorney General, Executive Branch officials and Chadha, all outside the legislative branch." $103 \mathrm{~S}$. Ct. at 2784. The Justices could not, however, have meant to make a complete statement of a constitutional test. After all, the Senate's action in granting or refusing consent to a judicial nomination also has "the purpose and effect of altering the legal rights ... of persons ... outside the legislative branch." The distinction is that the power to advise and consent is granted elsewhere in the Constitution. But that cannot be the only distinction. See supra text accompanying note 133. It is still necessary to find a source, apart from placement in the document and effect on legal rights, for determining when Congress is exercising an "ordinary" legislative power.

${ }^{137}$ Most of what might be considered "good answers" were quite properly rejected in Chadha. But see supra note 136.

${ }^{138}$ See supra text accompanying notes 60-64.

130 See supra text accompanying notes 69-123. 
Again, these arguments may not be terribly convincing, and a judicial decision that section 5(c) is unconstitutional would do little violence to the system of checks and balances. The same cannot be said for section 5(b), however. That section's requirement that the President must remove American forces from combat unless he receives congressional permission within sixty days is surely constitutional, even after Chadha. ${ }^{140}$ Section $5(\mathrm{~b})$ is not a legislative veto. The limitation contained therein is the functional equivalent of a statute reading, "The President may not commit troops to combat for longer than sixty days unless this statute is amended," because the adoption of a joint resolution and the signing by the President causes the enactment of new positive law. A statute reading, "The President may not commit troops to combat for longer than sixty days unless this statute is amended," is the functional equivalent of a statute reading, "The President may not commit troops to combat for longer than sixty days"-period. This is so because the last clause ("unless this statute is amended") is an implied provision of every statute. This follows from the doctrine that one Congress may not bind a later one into leaving sacrosanct the statutes enacted by the first.

All of this reduces to the following proposition: section $5(\mathrm{~b})$ is the functional equivalent of a statute simply stating, "The President may not commit troops to combat for longer than sixty days." If the President wants to commit American forces for a longer period, he may seek the joint resolution provided for in the War Powers Resolution, or he may request separate enabling legislation-for the Congress that passed the War Powers Resolution cannot bind future Congresses either. Furthermore, the statute reading, "The President may not commit troops to combat for longer than sixty days," is certainly within the power of Congress under the analysis presented in this article. ${ }^{141}$ As a consequence, no matter what the constitutional status of section $5(\mathrm{c})$, section $5(\mathrm{~b})$ is a constitutionally permissible strategy for enforcing the congressional definition of the war power.

\footnotetext{
${ }^{140}$ See Chadha, $103 \mathrm{~S}$. Ct. at 2786 n.19 (dictum) (suggesting that "durational limits on authorizations ... . lie well within Congress' constitutional power").

${ }^{141}$ See supra text accompanying notes 69-78. Even if one assumes that the President's "sudden attack" authority, see supra text accompanying notes $42-45,70$, would survive this statute, there is no reason to think that any other presidential authority to use troops might.
} 


\section{Conclusion}

That the War Powers Resolution is constitutional will not end all the controversy over its requirements. There will still be those who will attack its provisions as unwise and perhaps demand its repeal; Presidents and members of Congress may continue to quarrel over what state of affairs constitutes the "hostilities" to which section 4 refers; and Congress might act foolishly under the Resolution, either ending wars that it ought to permit or permitting wars that it ought to stop. But all of that means only that the Resolution still has a considerable distance to grow. It represents one perhaps clumsy effort at dealing with a world that has become increasingly complex. For better or for worse, the United States possesses one of the two most powerful military machines the earth has ever known. That awesome power carries with it the awesome responsibility to use those forces wisely. The genius of the Resolution, with all of its faults, is this: It guarantees that unless the Congress of the United States gives its approval, all of that awesome power will not be concentrated in the hands of a single individual. For that guaranty, a degree of inefficiency and a handful of unwise decisions along the way seem a small price to pay. 